\title{
Empirical Yield Tables for Jack Pine
}

\author{
Michel Boudoux \\ Laurentian Forest Research Centre \\ P.O. Box 3800 \\ Sainte-Foy, Quebec GIV 4C7
}

\section{Research Note}

This is a summary of a work in the Proceedings of the Jack Pine Symposium published by the Quebec Official Publisher, 1978 .

The empirical yield tables were established on the basis of experimental results from 1300 sampleplots; the figures came from the data bank of the Service de I'Inventaire forestier of the Ministère des Terres et Forêts du Québec. This bank is made up of sample-plots of one tenth of an acre, established throughout Quebec and covering the various forest types in the province. For each sample-plot, the inventory service has a number of measurements, all referred to the acre. The following variables were used:

- total number of stems 1 inch and over (hardwood and softwood species), N1T

- basal area of stems 1 inch and over (hardwood and softwood species) G1T
- number of stems 1 to 3 inches (softwood species) N13R

- basal area of stems 1 to 3 inches (softwood species) G13R

- number of stems inches and over (hardwood and softwood species) N4T

- basal area of stems 4 inches and over (hardwood and softwood species), G4T

- merchantable volume of stems 4 inches and over (hardwood and softwood species), V4T

- number of stems 4 inches and over softwood species), N4R

- basal area of stems 4 inches and over (softwood species) G4R

- merchantable volume of stems 4 inches and over (softwood species), V4R

${ }^{1}$ This work may be obtained from the Laurentian Forest Research Centre, P.O. Box 3800 Sainte-Foy, Québec, G1V $4 \mathrm{C} 7$ a/s the director.

Table 1. Jack pine, class I Merchantable volumes (V4R) per acre and mean annual increments.

\begin{tabular}{|c|c|c|c|c|c|c|c|c|c|c|c|c|}
\hline & Basal & area, 1 & and & more $(C$ & & & & & & & & \\
\hline age $(A)$ & $\begin{array}{r}50 \\
\mathrm{~V} 4 \mathrm{R}\end{array}$ & & $\begin{array}{r}70 \\
\mathrm{~V} 4 \mathrm{R}\end{array}$ & & $\begin{array}{r}90 \\
\mathrm{~V} 4 \mathrm{R}\end{array}$ & & $\begin{array}{r}110 \\
\text { VR4 }\end{array}$ & & $\begin{array}{r}130 \\
\mathrm{~V} 4 \mathrm{R}\end{array}$ & & $\begin{array}{r}150 \\
\text { V4R }\end{array}$ & \\
\hline $30 .$. & 326 & 10.9 & 458 & 15.3 & 590 & 19.7 & 722 & 24.1 & 853 & 28.4 & 985 & 32.8 \\
\hline $35 \ldots$ & 499 & 14.2 & 672 & 19.2 & 845 & 24.1 & 1019 & 29.1 & 1192 & 34.1 & 1365 & 39 \\
\hline $40 \ldots \ldots \ldots \ldots \ldots$ & 642 & 16.1 & 847 & 21.2 & 1051 & 26.3 & 1255 & 31.4 & 1460 & 36.5 & 1664 & 41.6 \\
\hline $45 \ldots \ldots \ldots \ldots \ldots$ & 765 & 17 & 994 & 22.1 & 1223 & 27.2 & 1451 & 32.3 & 1680 & 37.3 & 1909 & 42.4 \\
\hline $50 \ldots \ldots \ldots \ldots \ldots$ & 873 & 17.5 & 1121 & 22.4 & 1369 & 27.4 & 1617 & 32.3 & 1865 & 37.3 & 2113 & 42.3 \\
\hline $55 \ldots \ldots \ldots \ldots \ldots$ & 970 & 17.6 & 1234 & 22.4 & 1497 & 27.2 & 1761 & 32 & 2025 & 36.8 & 2289 & 41.6 \\
\hline$\ldots \ldots \ldots$ & & & 1333 & 22.2 & 1611 & 26.8 & 1888 & 31.5 & 2165 & 36.1 & 2442 & 40.7 \\
\hline $65 \ldots \ldots \ldots \ldots \ldots$ & & & 1423 & 21.9 & 1711 & 26.3 & 2000 & 30.8 & 2288 & 35.2 & 2576 & 39.6 \\
\hline $70 \ldots$ & & & n & & 1802 & 25.7 & 2100 & 30 & 2398 & 34.3 & 2696 & 38.5 \\
\hline $75 \ldots$ & & & & & 1884 & 25.1 & 2190 & 29.2 & 2497 & 33.3 & 2803 & 37.4 \\
\hline $80 \ldots \ldots \ldots \ldots \ldots$ & & & & & 1959 & 24.5 & 2272 & 28.4 & 2585 & 32.3 & 2899 & 36.2 \\
\hline $85 \ldots \ldots \ldots \ldots \ldots$ & & & & & 2026 & 23.8 & 2346 & 27.6 & 2666 & 31.4 & 2985 & 35.1 \\
\hline $90 \ldots \ldots \ldots \ldots \ldots$ & & & & & 2087 & 23.2 & 2413 & 26.8 & 2738 & 30.4 & 3064 & 34 \\
\hline
\end{tabular}


- mean diameter (of trees 4 inches and over) at breast height, dbh

- mean age at $\mathrm{DBH}, \mathrm{A}$

- mean height of dominant and co-dominant storeys of the plot, $\mathrm{H}$.

These last three variables (DBH, $A$ and $H)$ do not come from a general measurement of all trees in the plot (as for the first ten variables) but are calculated (arithmetic mean) from three to five sample trees measured at the centre of the plot and chosen as being representative of that plot.

To these thirteen variables we added a fourteenth, the mean site index (SI) of the plot. The site index here is the mean height in feet at 50 years. Lundgren and Dolid's (1970) equation is used to calculate the site index. The results are appreciably the same as those obtained by Plonski (1971) or Bella (1968) for ages of less than 80 years.

On the basis of these calculated site indices two different site quality classes were distinguished:

class II: $35 \leq$ SI $<45$

class I: $\mathrm{SI} \geq 45$

From the above available material is produced empirical yield tables in three stages. The first stage was to build volume tables, which are basically static tables, giving a volume per acre for each stand of a given age, basal area and site quality. Tables of this kind do not, of course, give any indication of the past or future changes in the standing volume of the stands. Therefore the second stage was approached from a more dynamic view point, qualifying the mean change over time of the various parameters of the stand. Then mean yield tables for volume, diameter, basal area and so on were established. The last stage was to generalize the approach, giving possible growths, ranging from low yield to maximum yield for a given site.

A fairly simple general equation was used. It appeared that some non-linear models could prove doubtful in borderline cases. The equations used give the merchantable volume of the softwoods (in cubic feet per acre) as a function of the site index (SI), age (A), square of the age, total ( 1 inch and over) or merchantable ( 4 inches an over) basal area $(G)$ and the mean increment in basal area:

$$
\begin{aligned}
& \text { VAR }=-1918,620+21,117 \mathrm{G} 1+28,817 \text { IS } \\
& +17,632 \mathrm{~A}-0,060(\mathrm{~A})^{2}-435,859(\mathrm{G} 1 \div \mathrm{A}) \\
& \text { VAR }=-740,170+24,237 \mathrm{G} 4+12,171 \text { IS } \\
& -0,555 \mathrm{~A}+0,041(\mathrm{~A})^{2}-311,109(\mathrm{G} 4 \div \mathrm{A})
\end{aligned}
$$

The merchantable volume (V4R) calculated here is the merchantable volume of softwoods.

Tables of volume per acre for various ages, basal area (G1) and site classes (Tables 1 and 2) were constructed from these equations. For each volume the corresponding mean annual increment is given in italics.

Table 2. Jack pine, class II Merchantable volumes (V4R) per acre and mean annual increments.

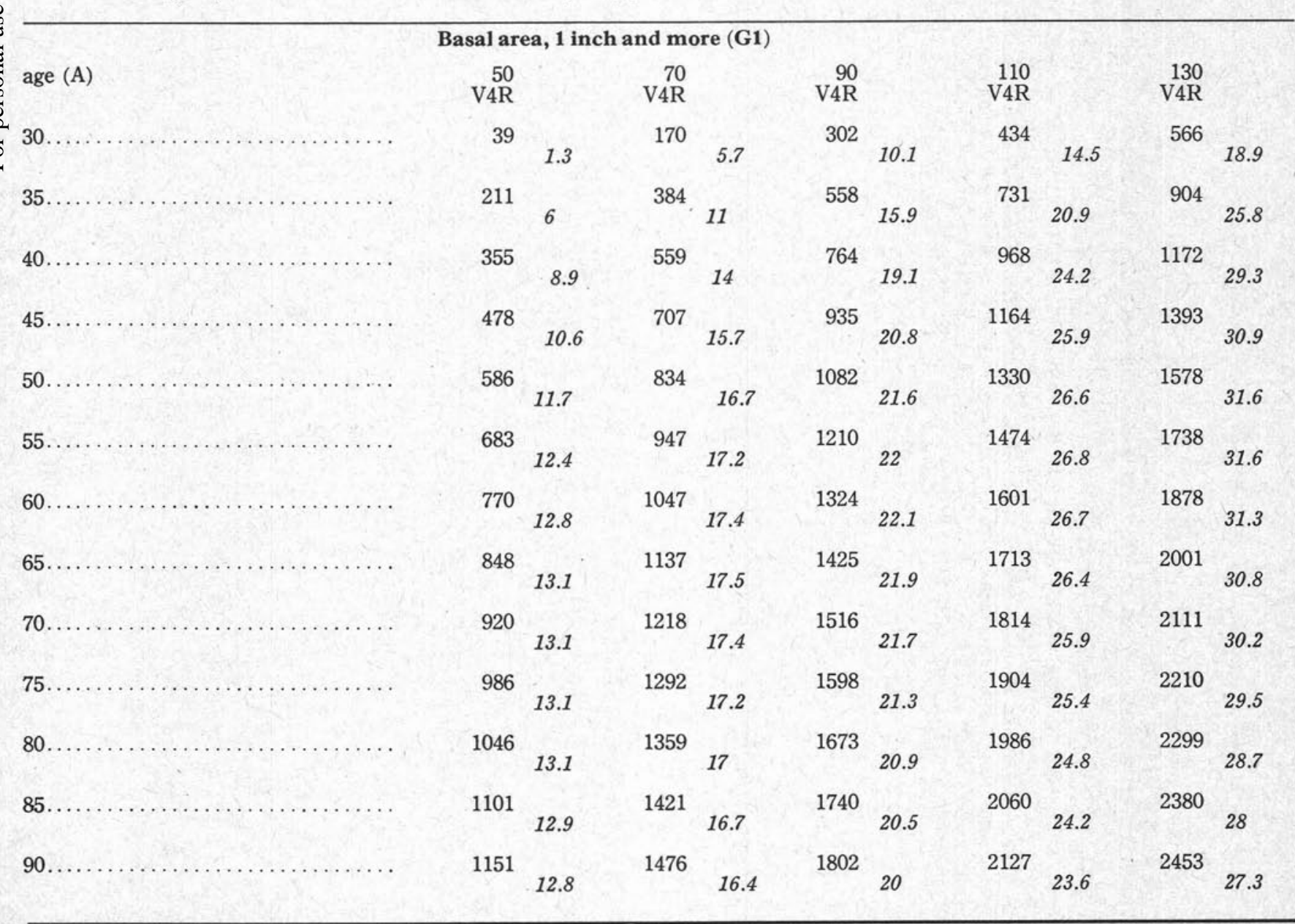


Table 3. Yield table for class I

\begin{tabular}{|c|c|c|c|c|c|c|c|c|c|c|}
\hline$\underset{\mathrm{A}}{\operatorname{age}}$ & $\begin{array}{c}\text { basal area } \\
\text { G1T } \\
\text { ft }^{2} / \text { acre }\end{array}$ & $\begin{array}{c}\text { merchantable } \\
\text { volume } \\
\text { V4R } \\
\mathrm{ft}^{3} / \mathrm{acre}\end{array}$ & $\begin{array}{l}\text { mean annual } \\
\text { increment } \\
\mathrm{ft}^{3} / \text { acre } / \text { year }\end{array}$ & $\begin{array}{c}\text { periodic } \\
\text { annual } \\
\text { increment } \\
\mathrm{ft}^{3} / \mathrm{acre} / \text { year }\end{array}$ & $\begin{array}{c}\text { number } \\
\text { of trees } \\
\left(1 \text { to } 3^{\prime \prime}\right)\end{array}$ & $\begin{array}{c}\text { number } \\
\text { of trees } \\
>4^{\prime \prime}\end{array}$ & $\begin{array}{l}\text { trees/ } \\
\text { cunit }\end{array}$ & $\underset{\mathrm{ft}^{3} / \mathrm{ft}^{2}}{\text { formheight }}$ & $\underset{\text { in }}{\text { merchantable }}$ & $\begin{array}{c}\text { mean } \\
\text { height }\end{array}$ \\
\hline $\begin{array}{l}30 \\
35 \\
40 \\
45 \\
50 \\
55 \\
60 \\
65 \\
70 \\
75 \\
80\end{array}$ & $\begin{array}{r}65 \\
78 \\
89 \\
99 \\
107 \\
113 \\
118 \\
121 \\
122 \\
122 \\
120\end{array}$ & $\begin{array}{r}424 \\
741 \\
1044 \\
1326 \\
1582 \\
1807 \\
2000 \\
2159 \\
2284 \\
2373 \\
2425\end{array}$ & $\begin{array}{l}14.1 \\
21.2 \\
26.1 \\
29.5 \\
31.6 \\
32.9 \\
33.3 \\
33.2 \\
32.6 \\
31.6 \\
30.3\end{array}$ & $\begin{array}{l}63.4 \\
60.7 \\
56.4 \\
51.1 \\
45.0 \\
38.6 \\
31.9 \\
24.9 \\
17.8 \\
10.5\end{array}$ & $\begin{array}{r}1095 \\
903 \\
732 \\
583 \\
454 \\
347 \\
261 \\
196 \\
152 \\
129 \\
128\end{array}$ & $\begin{array}{l}308 \\
398 \\
469 \\
520 \\
552 \\
565 \\
559 \\
533 \\
488 \\
424 \\
340\end{array}$ & $\begin{array}{l}72 \\
53 \\
44 \\
39 \\
34 \\
31 \\
27 \\
24 \\
21 \\
17 \\
14\end{array}$ & $\begin{array}{r}6.5 \\
9.5 \\
11.7 \\
13.4 \\
14.8 \\
15.9 \\
16.9 \\
17.8 \\
18.7 \\
19.5 \\
20.2\end{array}$ & $\begin{array}{l}4.7 \\
4.9 \\
5.2 \\
5.4 \\
5.7 \\
6.0 \\
6.3 \\
6.6 \\
6.9 \\
7.2 \\
7.5\end{array}$ & $\begin{array}{l}34 \\
39 \\
43 \\
46 \\
50 \\
53 \\
55 \\
57 \\
59 \\
61 \\
62\end{array}$ \\
\hline
\end{tabular}

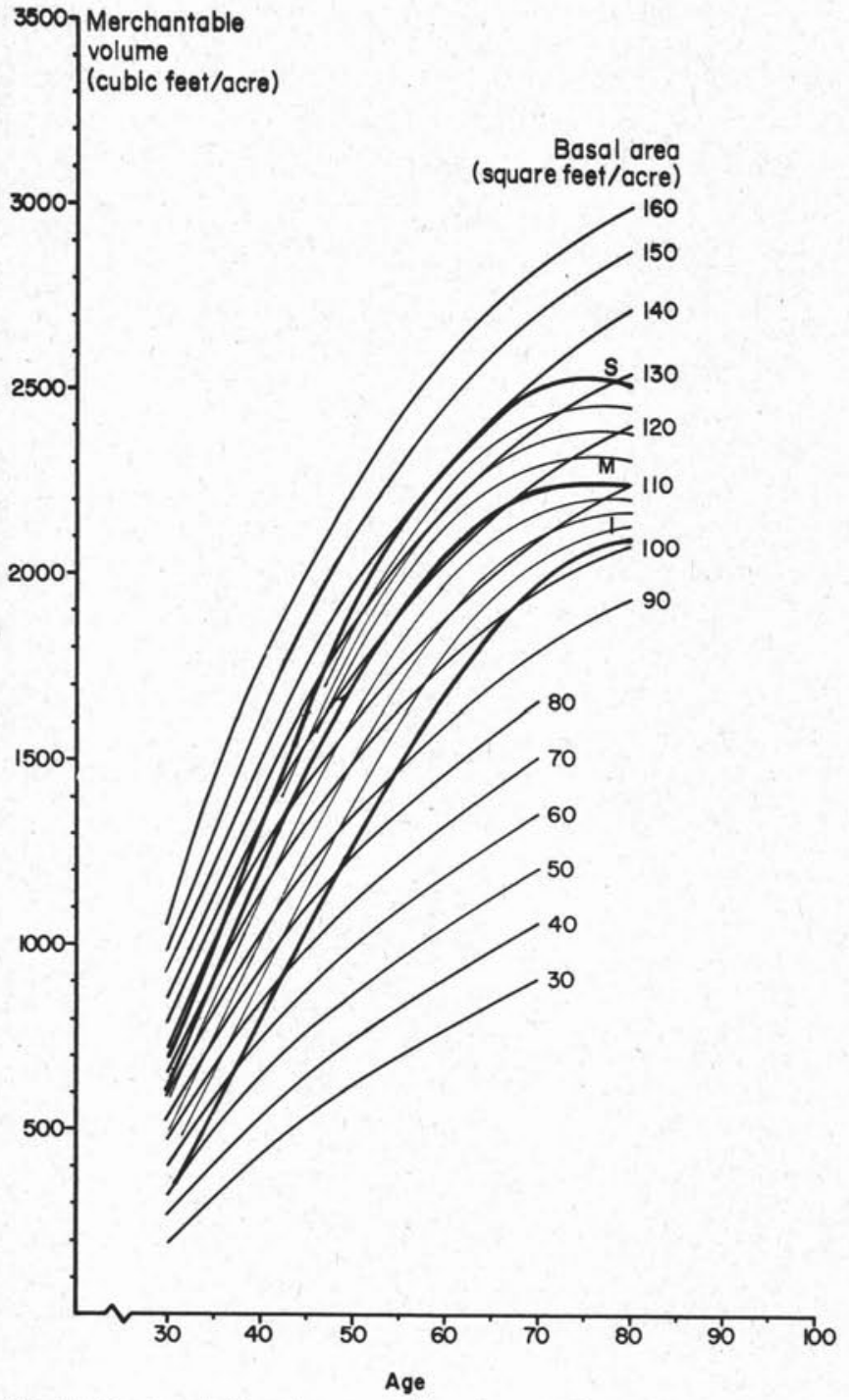

Fig. 1. Merchantable volume and basal area (class I).

The tables permit the calculation of the merchantable volume of a stand of known age and basal area, but are obviously no authority for any inference about what this same stand will be like ten or twenty years later. In other words, these are tables for volume per acre and are not yield tables.

The second stage was to establish, from the results, true yield tables, first for mean merchantable volumes and basal areas, and then for other important

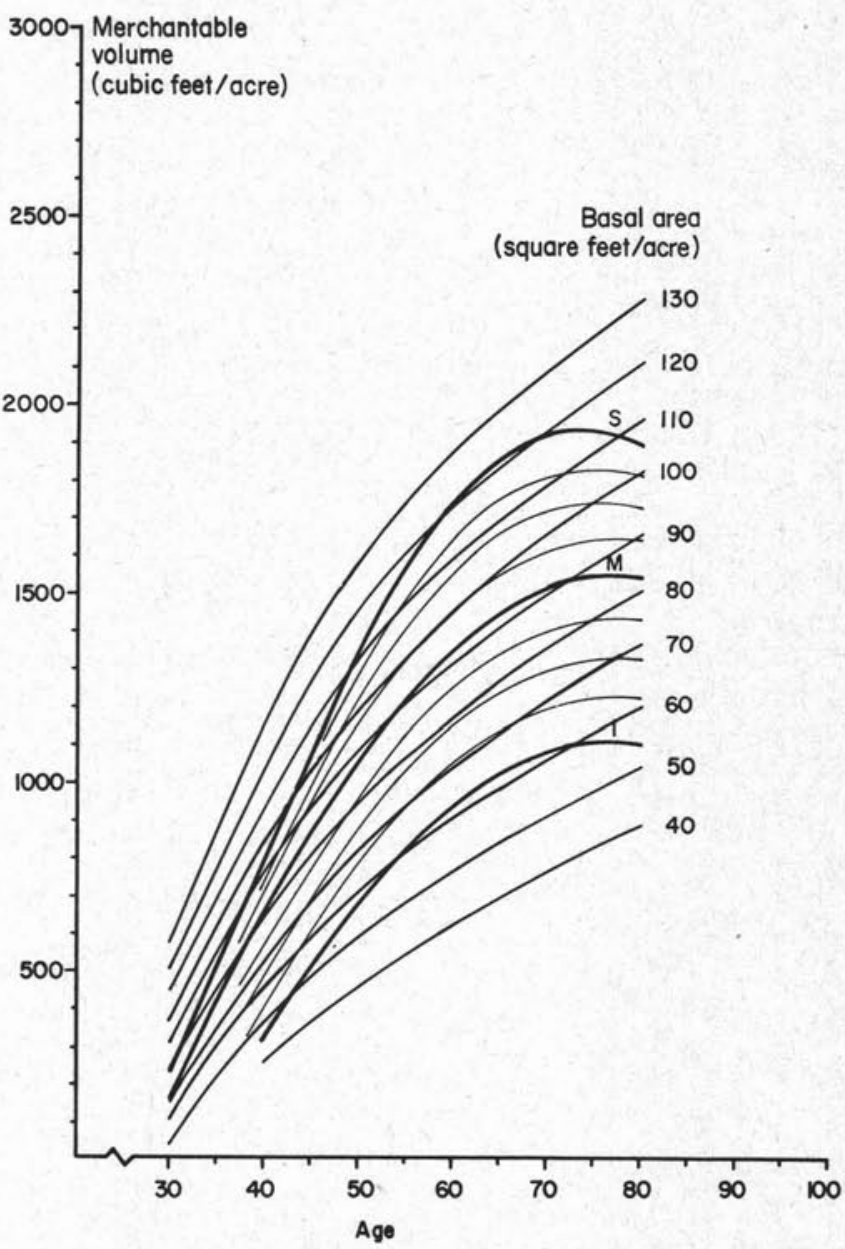

Fig. 2. Merchantable volume and basal area (class II).

parameters such as form height, number of stems in the cunit, and unit volume (Tables 3 and 4).

The third step, determines by means of the equations calculated (see above), a family of age/volume curves each one of which corresponds, for the site under study, to a constant basal area (see Fig. 1). Such curves are created by calculating equations, varying the age, keeping G1 constant and making SI equal to 50 . These curves of equal basal area obviously do not represent changes in the stands but they do introduce a third dimension into the chart.

With these curves established, we calculated for all of the pertinent plots the mean values for the total basal areas between 30 and 80 years by five-year 
Table 4. Yield table for class II

\begin{tabular}{|c|c|c|c|c|c|c|c|c|c|c|}
\hline$\underset{\mathbf{A}}{\operatorname{age}}$ & $\begin{array}{c}\text { basal area } \\
\text { G1T } \\
\mathrm{ft}^{2} / \mathrm{acre}\end{array}$ & $\begin{array}{l}\text { merchantable } \\
\text { volume } \\
\text { V4R } \\
\mathrm{ft}^{3} / \text { acre }\end{array}$ & $\begin{array}{c}\text { mean annual } \\
\text { increment } \\
\mathrm{ft}^{3} / \mathrm{acre} / \text { year }\end{array}$ & $\begin{array}{c}\text { periodic } \\
\text { annual } \\
\text { increment } \\
\mathrm{ft}^{3} / \text { acre } / \text { year }\end{array}$ & $\begin{array}{l}\text { number } \\
\text { of trees } \\
\left(1 \text { to } 3^{\prime \prime}\right)\end{array}$ & $\begin{array}{c}\text { number } \\
\text { of trees } \\
4^{\prime \prime}\end{array}$ & $\begin{array}{l}\text { trees/ } \\
\text { cunit }\end{array}$ & $\underset{f t^{3} / \mathrm{ft}^{2}}{\text { formheight }}$ & $\begin{array}{c}\text { Merchantable } \\
\text { dbh } \\
\text { in }\end{array}$ & $\begin{array}{c}\text { mean } \\
\text { height }\end{array}$ \\
\hline $\begin{array}{l}30 \\
35 \\
40 \\
45 \\
50 \\
55 \\
60 \\
65 \\
70 \\
75 \\
80\end{array}$ & $\begin{array}{l}43 \\
54 \\
64 \\
73 \\
79 \\
85 \\
89 \\
92 \\
93 \\
93 \\
91\end{array}$ & $\begin{array}{r}249 \\
499 \\
735 \\
951 \\
1143 \\
1309 \\
1448 \\
1558 \\
1638 \\
1687\end{array}$ & $\begin{array}{r}7.1 \\
12.5 \\
16.3 \\
19.0 \\
20.8 \\
21.8 \\
22.3 \\
22.3 \\
21.8 \\
21.1\end{array}$ & $\begin{array}{r}51.1 \\
50.1 \\
47.2 \\
43.2 \\
38.5 \\
33.3 \\
27.7 \\
21.9 \\
16.0 \\
9.9\end{array}$ & $\begin{array}{r}1026 \\
1020 \\
991 \\
938 \\
863 \\
764 \\
642 \\
498 \\
330 \\
139\end{array}$ & $\begin{array}{l}215 \\
305 \\
375 \\
426 \\
457 \\
469 \\
462 \\
435 \\
389 \\
324 \\
239\end{array}$ & $\begin{array}{r}122 \\
75 \\
58 \\
48 \\
41 \\
35 \\
30 \\
25 \\
19 \\
14\end{array}$ & $\begin{array}{r}4.6 \\
7.8 \\
10.1 \\
12.0 \\
13.5 \\
14.7 \\
15.8 \\
16.8 \\
17.7 \\
18.5\end{array}$ & $\begin{array}{l}4.4 \\
4.5 \\
4.7 \\
4.9 \\
5.1 \\
5.3 \\
5.6 \\
6.0 \\
6.3 \\
6.8 \\
7.2\end{array}$ & $\begin{array}{l}27 \\
31 \\
34 \\
37 \\
40 \\
43 \\
46 \\
48 \\
50 \\
53 \\
55\end{array}$ \\
\hline
\end{tabular}

class. This is curve $M$ (mean) of Figure 1. If this curve is projected on the vertical axis, the variation of the mean volume in relation to time can be read, and the basal area at a given age can be calculated by interpolation on the curves of equal area. In fact not one but several yield curves were established. The average yield curve (M) divides up all plots and distinguishes a first subset made up of plots whose volume is greater than the mean volume of the same age (curve $M$ ) and symmetrically distinguishes a second subset made up of those plots whose volume is less than the mean volume. In our example the mean curve of the first subset was calculated and designated as $\mathrm{S}$ (Figure 1). This curve $\mathrm{G} 1(\mathrm{~S})$ or more simply $S$ is therefore the mean curve of the higher basal areas. The same operation was carried out for the lower subset. The curve $\mathrm{G}_{1}(\mathrm{I})$ or $\mathrm{I}$ is the mean curve of the lower subset. Then the space was divided into 4 proportional parts between the curves $\mathrm{S}$ and $\mathrm{M}$ and $\mathrm{M}$ and $\mathrm{I}$. In this way intermediary curves were pro- duced (Fig. 1). a cluster of nine regularly spaced curves between curve I and curve $S$ are available for each site class. The result is two nomograms (Figures 1 and 2) from which the probable changes in volume and basal areas of any stand having a given basal area at a given age can be estimated.

\section{References}

Belia, I. E. 1968. Jack pine yield tables for southeastern Manitoba. Can. Dep. Fish. For. Publ. no. 1207.

Boudoux, M. 1978. Tables de rendement empiriques pour l'épinette noire, le sapin baumier et le pin gris du Québec. Ministère des Terres et Forêts du Québec.

Lundgren, A. L. and W. A. Dolid 1970. Biological growth functions describe published site index curves for Lake States timber species. U.S. For. Serv. Res. pap. NC-36.

Plonski, W. L. 1971. Normal yield tables for Black Spruce, Jack Pine, Aspen and White Birch in Northern Ontario. Ont. Dep. Lands. For. Timber. Man. Div. Rep. no. 24. 